\title{
PERAN PENDIDIKAN SEJARAH DALAM PENGEMBANGAN PENGAJARAN PENDIDIKAN MULTIKULTUR DI LPTK
}

\author{
Soebijantoro ${ }^{1}$ )
}

\begin{abstract}
Abstrak
Karakteristik masyarakat Indonesia dapat ditunjukkan dengan keragaman, baik suku, bahasa, agama, budaya maupun adat istiadat. Dalam konteks berbangsa dan bernegara, maka kesadaran akan sifat humanis, pluralis dan demokratis di atas keragaman merupakan sebuah tuntutan. Kristalisasi budaya atas sifat-sifat tersebut telah tercatat dalam perjalanan panjang sejarah Indonesia. Pendidikan multikultur di Lembaga Pendidikan Tenaga Kependidikan (LPTK) diharapkan dapat menumbuhkan empati bagi calon-calon guru yang melihat bahwa keragaman adalah sebuah kenyataan, bukan sesuatu yang harus dihindari. Pendidikan sejarah diharapkan dapat mengantarkan kesadaran itu melalui pengembangan pembelajaran berbasis kultural dengan acuan pengalaman kolektif bangsa Indonesia.
\end{abstract}

\section{Kata kunci: Pendidikan Sejarah, Pendidikan Multikultur}




\section{Pendahuluan}

Terdapat dua peristiwa menarik sebagai sebuah refleksi bangsa Indonesia di akhir tahun 2010. Peristiwa pertama adalah polemik Rancangan Undang-undang Keistemewaan (RUUK) Yogyakarta yang masih menjadi perdebatan, baik ditingkat pusat maupun di daerah. Sedang peristiwa kedua adalah euforia prestasi spektakuler tim sepakbola Indonesia yang berhasil menembus final Piala AFF 2010. Sekilas kedua peristiwa tersebut tidak memiliki relevansi yang berbasis kepentingan praktis bagi masyarakat. Polemik RUUK melibatkan penyelesaian dalam ranah hukum tatanegara, sedangkan disisi lain sepak bola berkenaan dengan prestasi dibidang olah raga. Namun apabila kita cermati lebih dalam, sesungguhnya dua peristiwa tersebut memiliki kesadaran nilai (value) harapan, cita-cita akan jati diri sebagai bangsa yang mewarisi budaya besar. Apapun bentuk reaksi masyarakat Yogyakarta atas polemik tentang status keistimewaan tersebut harus kita hargai sebagai sebuah apresiasi masyarakat yang merefleksikan bahwa Yogyakarta tidak hanya memiliki keistimewaan dalam mekanisme pemerintahan dalam sejarah republik Indonesia saja, akan tetapi juga kontinuitas kehidupan tradisi masyarakat Yogyakarta di tengah heterogenitas dari konsekuensi sebagai kota pendidikan.
Seperti halnya dengan polemik keistimewaan tersebut di atas, maka prestasi yang ditorehkan oleh tim sepak bola nasional dalam menembus final Piala AFF seolah menggugah kembali kepedulian kita akan prestasi terbaik sepak bola Indonesia yang terus terpuruk dengan hasil terbaik yang dicapai pada even Asian Games tahun 1958 yaitu meraih medali perunggu (Nugroho Notosusanto, 1984).

Para pendiri bangsa kita menyadari bahwa sepak bola adalah salah satu media yang kuat dalam membangun harga diri dan martabat bangsa serta kebersamaan yang dibalut dalam nasionalisme melalui sense of spirit maupun sense of defence. Potret sejarah sepak bola Indonesia dibangun di atas kesadaran akan keberagaman suku bahasa dan budaya untuk menuju pencapaian harkat dan martabat sebagai bangsa yang berdaulat. Sehingga prestasi Indonesia dalam event Piala AFF seolah sebagai pelepas dahaga akan keinginan bangkitnya sepakbola Indonesia di tengah keterpurukan carut marut persoalan bangsa. Salah satu persoalan yang dihadapi bangsa Indonesia saat ini adalah perjalanan akan kesadaran bangsa atas keragaman suku bahasa dan budaya sebagai potret bangsa Indonesia. Sartono Kartodirjo 
(1999:289) mengatakan bahwa sejumlah persoalan besar yang dihadapi oleh bangsa Indonesia saat ini adalah berkisar pada masalah prasangka religious, sentimen antar etnik, eklusivisme sektarianisme dan komunalisme yang bermuara pada transformasi struktural masyarakat Indonesia dalam segala dimensinya. Problem tersebut tidak lepas dari kemajemukan masyarakat Indonesia dan untuk saat ini sangat diperlukan upaya untuk merekonstruksi kembali kebudayaan nasional sebagai kekuatan untuk menyatukan keragaman.

Rekonstruksi kembali kebudayaan nasional akan dapat dilakukan apabila terdapat pemahaman akan potret keragaman budaya sebagai dasar terbentuknya sebuah nation. Indonesia adalah salah satu negara multikultur terbesar di dunia. Kondisi sosiokultural maupun geografis yang beragam dan luas sudah cukup untuk membuktikan hal itu. Tidak mudah untuk mewujudkan rekonstruksi tersebut. Salah satu diantaranya adalah munculnya keraguan akan perlunya nasionalisme di tengah arus global saat ini. Sartono Kartodirjo dalam Anhar Gongong (2008:68) mengatakan bahwa nasionalisme adalah sebuah perspektif sejarah, artinya bahwa dengan memahami sejarah maka kita akan mengetahui pula per- tumbuhan nasionalisme termasuk komponen-komponen bangsa dalam mewujudkan nasionalisme tersebut.

Apabila diamati dari segi pembangunan bangsa, maka pemahaman akan sejarah bangsa adalah sebuah tuntutan dan lembaga pendidikan formal merupakan media untuk mewujudkan keinginan tersebut. Sejarah penting diberikan di lembaga pendidikan formal. Pernyataan ini mengacu pada pentingnya hubungan antara sejarah dengan pendidikan. Secara lebih khusus pendidikan pada dasarnya memiliki ide-ide pokok yaitu usaha pengembangan daya-daya manusia agar dengan pendidikan manusia dapat membangun dirinya dan besama dengan sesamanya membudayakan alamnya dan membangun masyarakatnya (Ali Moertopo, 1978:34). Rumusan ini apabila dikaji secara mendalam akan mencerminkan unsur pokok dari proses dasar kehidupan sosial manusia yaitu proses sosialisasi dan inkulturasi. Proses ini berupa pewarisan dan penuturan nilainilai sosial kultural pada individu-individu sebagai anggota kelompok. Dengan kata lain nilainilai yang berkembang pada generasi muda terdahulu perlu diwariskan kepada generasi masa kini, bukan saja untuk integrasi individu ke dalam kelompok te- 
tapi juga sebagai bekal kekuatan untuk menghadapi masa kini dan masa yang akan datang. Lebihlebih apabila disadari bahwa tujuan pendidikan nasional pada dasarnya adalah ingin mengembangkan manusia Indonesia seutuhnya.

Dengan demikian, apabila pendidikan dianggap sebagai suatu sarana untuk mewujudkan cita-cita nasional, maka sejarah pada hakekatnya merupakan sumber kekuatan bagi sarana tersebut secara efektif. Untuk dapat menumbuhkan jiwa patriot dan mempertebal rasa cinta tanah air, meningkatkan semangat kebangsaan dan kesetiakawanan sosial serta kesadaran pada sejarah bangsa dan sikap menghargai para pahlawan serta berorientasi ke masa depan, maka pengajaran sejarah mempunyai fungsi yang sangat fundamental. Oleh karena itu pengajaran sejarah di sekolah-sekolah termasuk keberadaan program studi pendidikan sejarah di lembaga pendidikan tinggi keguruan sebagai wadah pencetak guru professional dituntut untuk dapat mewujudkan misi pengajaran sejarah tersebut. Diperlukan sebuah strategi melalui visi dan misi program studi yang matang mengingat output LPTK adalah tenaga kependidikan yang akan mengabdikan dirinya di seluruh penjuru tanah air dan keberada- annya memerlukan pemahaman yang sangat kuat tentang keberagaman dalam kehidupan masyarakat dan Negara.

\section{Realitas Pendidikan Multikultur}

Kondisi sosiokultural maupun geografis Indonesia dapat ditunjukkan dengan dengan jumlah populasi penduduk lebih dari 200 juta jiwa yang menempati 13.000 pulau baik besar maupun kecil dengan kurang lebih 250 bahasa yang berbeda. Selain itu mereka juga menganut agama dan kepercayaan yang berbeda (Rochiati Wiriaatmadja, 2004:64). Dengan demikian keragaman-keragaman tersebut diakui atau tidak dapat menimbulkan berbagai persoalan yang carut marut seperti yang kita lihat selama ini seperti intrik politik, anarkisme, kemiskinan, korupsi yang tidak berkesudahan. Sejarah panjang Indonesia telah menunjukkan bukti-bukti tersebut. Berkaitan dengan hal tersebut perlu sebuah strategi pemecahan melalui multidimensional approach (Soerjanto Poespowardojo, 1993:10). Pendidikan multikultur merupakan media yang menawarkan satu alternatif melalui penerapan strategi dan konsep pendidikan yang berbasis pada pemanfaatan keragaman yang ada di masyarakat 
kepada mahasiswa akan keragaman etnis, bahasa, agama dan budaya.

Pendidikan multikultur tidak hanya bertujuan agar supaya generasi muda mudah memahami materi pelajaran yang dipelajari, akan tetapi juga dapat meningkatkan kesadaran agar selalu berperilaku humanis, pluralis dan demokratis. Hal ini merupakan bagian dari sebuah proses. Sebagai sebuah strategi dan konsep pendidikan berbasis keragaman budaya, maka pendidikan multikultur memaparkan proses perkembangan kultur yaitu inkulturasi dan sosialisasi (Ainul Yaqin, 2005:13). Proses inkulturasi menjelaskan bahwa dalam sebuah kelompok masyarakat akan mempunyai kultur sesuai dengan kelompoknya sehingga akan terjadi sebuah proses pewarisan nilai yang dilakukan secara turun temurun. Sedangkan proses sosialisasi me-negaskan adanya transfer budaya berupa nilai, norma, etika melalui proses pembelajaran secara sosial dalam kehidupan sehari-hari. Adalah merupakan hal yang menarik ketika persoalan baru muncul saat ini ketika Indonesia baru saja keluar dari rezim impresif (Orde Baru) dan memasuki era demokratis, keterbukaan dan reformasi. Tampak bahwa demokratisasi tidak selalu dimanfaatkan secara positif dalam koridor persatuan bangsa, akan tetapi sebaliknya justru digunakan untuk mengartikulasikan dendam-dendam dan ambisi-ambisi politik tanpa memperlihatkan kepentingan persatuan bangsa.

Kondisi tersebut diatas kalau kita lihat dapat berdampak pada ketenangan dan ketertiban (rust and order) dan stabilitas yang dicapai selama pemerintahan Orde Baru merupakan kondisi integrasi yang semu karena berangkat dari strategi impresif. Untuk itulah diperlukan perspektif baru yang menyangkut hubungan antar wilayah, kesatuan sosial dan politik. Dalam konteks inilah akar-akar sosial, politik, ekonomi dan budaya menjadi landasan hubungan antar wilayah baik dalam bentuk friendship (persahabatan, diplomasi) maupun manajemen konflik (Singgih Tri Sulistyono, 2005:44-45). Sehingga keragaman kultur Indonesia dapat memberikan peluang implementasi etnosentrisme dan relativisme kultur yang tidak bertanggung jawab. Harus kita akui bahwa etnosentrisme akan menempatkan manusia dengan pandangannya menganggap bahwa tingkah laku, adat istiadat maupun pemikirannya adalah paling benar, paling bermoral dan paling beradab. Pendidikan multikultur menegaskan perlunya kearifan dalam mengukur kultur lain dan tidak cenderung subyek- 
tif maupun egois karena setiap kultur tidak lepas dari relativisme kultur bahwa suatu kultur tidak dapat diukur dengan menggunakan standar yang pada kultur lain. Dengan kata lain bahwa semua kultur dalam relativisme kultur mempunyai posisi dan penghormatan yang sama, meskipun kadangkala terdapat ungkapan yang kurang puas (Ainul Yaqin, 2005:15). Sehingga dalam realitas kehidupan diperlukan adanya standar moral dan keadilan universal yang menjadi acuan umum dan harus ditaati agar tidak terjadi tindakan impresif atas sebuah kultur.

Kesadaran untuk berperilaku humanis, pluralis dan demokratis sebagai bagian dari tujuan pendidikan multikultur tidak akan dapat terwujud tanpa ketersediaan media kultur yang yang mendampinginya. Salah satu diantaranya adalah melalui media pendidikan sejarah. Kajian-kajian historis atas problem kultur bangsa saat ini sangat urgen untuk dilakukan. Penelitian historis akan memberikan lapangan kajian yang luas mengenai komunikasi lintas budaya (cross cultural communication) antara satu komunitas dengan komunitas lain yang menjadi dasar bagi proses integrasi di kalangan masyarakat Indonesia. Dalam konteks berbangsa dan bernegara tampak bahwa integrasi nasional seperti di Indonesia adalah sebuah keharusan. Proses pemaknaan integrasi nasional tidak hanya berangkat dari epistemologi politik semata, namun lebih dari itu bahwa integrasi nasional harus dapat dimaknai dari kesadaran akan keberadaan keragaman kultur bangsa Indonesia. Dengan demikian diharapkan penulisan sejarah nasional Indonesia yang menekankan pada penggunaan "paradigma integrasi" mempunyai kontribusi yang sangat besar dalam memperkuat proses integrasi nasional (Singgih Tri Sulistyono, 2004:45).

\section{Pendidikan Sejarah dan Pendidikan Multikultur di LPTK}

Abad ke-21 ditandai dengan perubahan-perubahan yang sangat bersifat multidimensional yang menuntut kita sebagai subyek sejarah untuk memahami dan menanggapai berbagai kecenderungan agar sebagai pendidik dapat mempersiapkan diri untuk tugas-tugas pembimbingan akan kehidupan pada masa depan peserta didik kita. Karena sesungguhnya peserta didik itulah yang nanti akan berjuang pada abad ke-21 ini.

Berbagai tranformasi yang terjadi mengikuti perubahan tersebut yang pada gilirannya menuntut peserta didik untuk 
berkembang menjadi manusiamanusia yang berwawasan luas, memiliki kepribadian dan kesusilaan yang tinggi dan fleksibel dalam menghadapi arus perubahan serta mampu menyesuaikan diri dengan tuntutan masa depan. Tuntutan yang tinggi tidak lain demi kepentingan survival yang bersangkutan dalam kehidupan yang penuh dengan tantangan dan ketidakpastian, persaingan dan ketepatan dalam pengambilan keputusan.

Tujuan pendidikan yang ingin memberikan arahan kepada peserta didik dalam pencarian kehidupan yang penuh makna seringkali terabaikan oleh sebuah dorongan pemenuhan kebutuhan dalam skala pendek. Koreksi ke arah proses pendewasaan akan banyak terbantu apabila sebagai pendidik dapat melakukan perenungan atau berpikir reflektif dalam relativisme pada perubahan yang multidimensional ini (Rochiati Wiriatmadja, 2000: 29). Salah satu bagian yang tidak terlepaskan dari tanggung jawab moral tersebut adalah keberadaan program studi pendidikan sejarah dalam mekanisme pendidikan formal.

Sejarah termasuk disiplin ilmu baik arts maupun humaniora. Sedangkan kajiannya yang bersifat sinkronik menjadikan ilmu sejarah termasuk ke dalam ilmu sosial. Urgensi bahwa terdapat relevansi antara tantangan dan tanggapan (challenge and response) terhadap perubahan-perubahan yang multidimensional dalam menghadapi masa depan dengan mempelajari masa lampau adalah sebuah keharusan. Sejarah adalah salah satu wahana pendidikan tertua di Indonesia, baik dalam perkembangan pendidikan sebelum maupun sesudah kemerdekaan. Sebagai mata pelajaran, sejarah sudah diajarkan sejak masa penjajahan Belanda. Pada masa penjajahan Belanda siswa belajar sejarah Belanda yang diberi judul Geschiedenis van Vaderlands (Said Hamid Hasan, 2004:6). Pada masa pendudukan Jepang mata pelajaran sejarah memegang peran penting pada penekanan arti penting perang Asia Timur Raya bagi Indonesia. Hingga masa kemerdekaan Indonesia, kurikulum mata pelajaran sejarah telah mengalami pasang surut. Satu hal yang menarik dalam kurikulum tersebut adalah aspek terwujudnya integrasi bangsa melalui pembelajaran sejarah.

Pembelajaran sejarah tidak lepas dari kajian sosiokultural baik dalam konteks materi pelajaran maupun dalam kegiatan belajar mengajar itu sendiri. Materi pelajaran sejarah merupakan gambaran produk budaya bangsa. Dalam rekaman sejarah terdapat jejak aktualisasi wujud budaya 
baik dalam bentuk abstrak, riil maupun fisik. Dalam sejarah Indonesia, perwujudan tersebut tercermin dalam paparan kurikulum. Adapun kegiatan belajar mengajar di kelas merupakan wujud kebudayaan yaitu sebuah aktifitas yang berpola. Terkait dengan hal itu, salah satu problematika pembelajaran sejarah adalah capaian dari tujuan pembelajaran sejarah itu sendiri, yaitu seringnya kita mendengar adanya keluhan dari siswa bahkan mahasiswa yang mengatakan bahwa mata pelajaran sejarah adalah mata pelajaran yang membosankan. Suatu persoalan yang harus kita terima sebagai sebuah realita bahwa telah terjadi sesuatu yang salah dalam pembelajaran sejarah kita, baik yang menyangkut materi maupun metode pengajaran dan pembelajarannya.

Terkait dengan hal tersebut di atas, dalam konteks pendidikan multikultur sebagai bagian dari kajian historis, seringkali pula kita mendengar bahwa kesadaran akan keragaman budaya harus diberikan dalam proses pendidikan formal. Meskipun tidak spesifik menunjuk pada mata pelajaran atau pendidikan multikultur, namun dalam praktik beberapa mata pelajaran telah berupaya (paling tidak) mengakomodir perlunya kesadaran akan adanya keberagaman bu- daya. Di tingkat LPTK meskipun tidak semua kurikulum program studi memuat secara khusus pendidikan multikultur, namun terdapat beberapa mata kuliah yang dapat digunakan sebagai media penyadaran tersebut yang terintegrasi seperti MKPK (Mata Kuliah Pengembangan Kepribadian), MKK (Mata Kuliah Keilmuan dan Keterampilan), MBB (Mata Kuliah Berkehidupan Bermasyarakat). Artinya terdapat mata kuliah yang spesifik harus ditempuh oleh seluruh mahasiswa apapun program studinya maupun yang mata kuliah yang spesifik melekat pada karakteristik program studi. Namun yang jelas kesemuanya bermuara untuk membekali soft skill calon guru agar memiliki sensitifitas dan daya pikir yang kritis dalam menyikapi kondisi lingkungan, memiliki rasa tanggung jawab, dan mampu bekerja keras dalam menjalankan profesinya sebagai tenaga pendidik yang professional.

Oleh karena tujuan dari pendidikan multikultur adalah membangun kesadaran agar berperilaku humanis, pluralis dan demokratis, maka penulis melihat bahwa terdapat alternatif penguatan pendidikan multikultur di LPTK. Pertama, konsistensi pengambil kebijakan di LPTK yang memandang bahwa pendidikan multikultur wajib di- 
masukkan kedalam kurikulum program studi. Kedua kontribusi dari staf pengajar pendidikan sejarah dalam penguatan materi pendidikan multikultur di LPTK melalui pengayaan materi yang tidak bersifat verbalistis. Apalagi dalam pengajaran sejarah harus dihindari sedapat mungkin munculnya apresiasi siswa terhadap fakta sejarah. Menurut CP. Hill (1956: 35) dalam proses belajar mengajar mata pelajaran sejarah terdapat dua komponen yang berpengaruh bagi keberhasilan siswa yaitu komponen guru dan komponen subyek belajar (siswa). Guru berperan sebagai pemimpin yang bertugas mengorganisir dan mempengaruhi perilaku tertentu sehingga terjadi proses belajar mengajar sejarah yang dapat mengkondisikan agar siswa tetap mempunyai hubungan yang hidup dengan mata pelajaran itu sendiri.

Agar siswa tetap mempunyai hubungan yang hidup dengan mata pelajaran, maka dalam kajian kultur diperlukan adanya pengembangan pengajaran melalui strategi kebudayaan, yaitu:

1. Pengembangan topik manusia dalam perspektif kebudayaan yang meliputi hakekat manusia dalam perspektif filsafat manusia, perilaku kebudayaan dan polemik kebudayaan.

2. Realitas sosial kemasyarakatan Indonesia yang meliputi struk- tur sosial masyarakat Indonesia, mentalitas manusia Indonesia dan kebijakan-kebijakan pengembangan kebudayaan Indonesia.

3. Pancasila dan sistem nilai masyarakat Indonesia yang meliputi jati diri manusia Indonesia dan nilai-nilai instrumental yang mendorong modernitas.

4. Ketahanan nasional dalam perspsektif kebudayaan yang meliputi masalah tantangan masa depan (Soerjanto Poespowardojo, 1993:15).

Strategi kebudayaan tersebut mengingatkan kepada kita pentingnya pendekatan budaya bahwa jalan apapun yang ditempuh dalam pembangunan suatu bangsa, maka manusialah yang tetap sebagai tujuan dan subyek pembangunan dalam artian bahwa melalui pendekatan kebudayaan, maka manusia diletakkan dalam posisi sentral. Apalagi pembangunan suatu bangsa termasuk Indonesia dapat dipastikan akan berorientasi ke depan sehingga diperlukan adanya individu dengan 3 (tiga) karakteristik khas yaitu kepekaan, kemandirian dan tanggung jawab (Emil Salim dalam Soerjanto Poespowardojo, 1993:30).

Harus diakui bahwa dua hal tersebut mengandung berbagai macam konsekuensi yang harus ditanggung LPTK mulai dari aspek 
finansial maupun ketersediaan sumber daya manusia yang memiliki kompetensi dalam bidang ini. Sebagai sebuah perguruan tinggi unggulan, maka IKIP PGRI Madiun dalam rangka mewujudkan misi perguruan tinggi yaitu mengembangkan sumber daya manusia di bidang kependidikan yang profesional dan memiliki kemampuan kompetetif dalam peningkatan kualitas hidup dan kehidupannya di tingkat regional serta misi melaksanakan Tri Dharma Perguruan Tinggi dalam rangka menghasilkan lulusan yang profesional dan memiliki kemampuan kompetetif dalam pendidikan sejarah, mampu melaksanakan penelitian dan pengabdian kepada masyarakat, maka sudah sewajarnya harus membekali semua mahasiswa sebagai calon guru profesional yang melihat bahwa multi kultur adalah sebuah nilai (value) yang sangat vital untuk menjamin kelangsungan hidup kedepan. Mengingat di tangan merekalah ke depan nasib bangsa ini akan ditentukan.

\section{Penutup}

Dari uraian tersebut, dapat ditarik sebuah simpulan bahwa pendidikan multikultur akan bergerak pada poros perlunya untuk memahami dan menerima akan adanya perbedaan maupun keragaman. Indonesia adalah salah satu negara yang memiliki karakter keragaman dan perbedaan kultur yang sangat kompleks sehingga berpotensi untuk terjadinya konflik. Untuk itu strategi yang tepat dalam transformasi sosial adalah melalui pendidikan. Pendidikan sejarah mempunyai peran dan kedudukan yang penting dalam pengembangan pengajaran multi-kulktur di LPTK. Idealisme pengembangan skill mahasiswa yang berangkat dari pembelajaran di program studi masing-masing diharapkan tidak akan berbenturan dalam praktik kehidupan yang nyata. Melalui kontribusinya, pendidikan multikultur dapat menanamkan sifat keterbukaan atas pluralisme individu di tengahtengah masyarakat. 


\section{Daftar Pustaka}

Ainul Yaqin. 2005. Pendidikan Multikultural. Yogyakarta: Pilar Media.

Ali Moertopo. 1978. Strategi Kebudayaan. Jakarta: CSIS.

Gardiner, P. 1959. Theories of History. London: Collier Macmillan Publishers.

Hill, CP. 1956. Saran-saran tentang Mengajarkan Sejarah. Terjemah Haksan Wira Sutisna. Jakarta. Perpustakaan Perguruan Kementrian $\mathrm{P}$ dan $\mathrm{K}$.

Rochiati Wiriaatmadja. 2004. Multicultural Perspektive In Teaching History to the Chinese Indonesian Students. Dalam Hitoria Nomor 9 Volume V. Bandung: Pend. Sejarah UPI.

Said Hamid Hasan. 2004. Pandangan Dasar Mengenai Kurikulum Pendidikan Sejarah. Dalam Historia Nomor 1 Volume 1. Bandung: Pend. Sejarah UPI.

Sartono Kartodirdjo. 1999. Ideologi dan Teknologi dalam Pembangunan bangsa: Eksplorasi Dimensi Historis dan Sosio Kulktural. Jakarta: Pabelan Jayakarta.

Singgih Tri Sulistyono. 2008. Sejarah Maritim Nusantara Perkembangan dan Prospeknya. Dalam Sejarah yang Memihak editor M. Nursam. Yogyakarta: Ombak.

Soerjanto Poespowardojo. 1993. Strategi Kebudayaan. Jakarta: Gramedia. 